\title{
A história da princesa guerreira
}

\section{Júlia Estefany Araújo}

DOI: https://doi.org/10.31692/978-65-88970-22.6-11

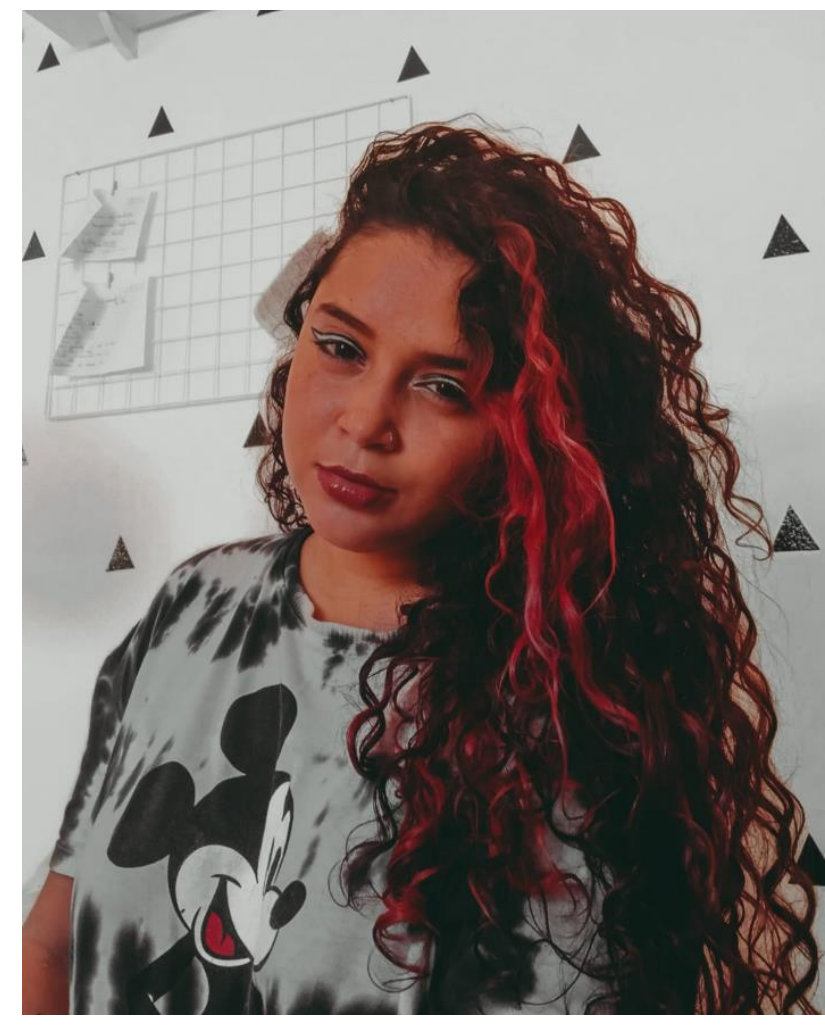

Meu nome é Júlia Estefany Araújo Barbosa, nascida em Recife, no dia 5 de julho de 2002, e tenho muita história para contar, sou fruto de uma relação entre uma adolescente, Gilcianny Araújo Pinheiro, e meu pai biológico, com quem não tenho contato há muitos anos; fui criada pela minha avó, a qual chamo de “Mainha Tata” e o marido dela, Aucresio, que me assumiu como filha, mesmo sendo ele, na época em que nasci, apenas namorado da minha avó, e não tendo obrigação nenhuma, disse para ela que estariam juntos nessa, e assim, me assumiu como filha, sou muito grata aos meus pais.

Minha mãe engravidou de mim aos 15 anos, largou a escola muito cedo, na $6^{\circ}$ série, e não tinha condições de criar uma criança; então voltou a morar com minha avó, porque tinha fugido de casa aos 12 anos para ficar com meu pai biológico. Ao nascer, contraí uma infecção hospitalar que me deixou internada no hospital por muitos dias, resultando em uma deficiência visual, com a qual convivo com ela até hoje. Fui uma guerreira, lutei contra a infecção e, com 28 dias de nascida, finalmente pude ir para casa, estava de alta.

A partir de então começou a saga da Júlia. Mesmo não tendo sido uma bebê planejada, fui recebida pela minha família com muito amor e carinho na casa da minha avó, com quem moro até hoje; lá eu tinha meu quartinho arrumado, lá estavam todos 
que amo a me esperar; porém havia alguma coisa estranha em mim, meus familiares perceberam que meus olhos não fixavam em ponto algum para olhar; segundo minha tia, meus olhos dançavam, meu olhar era perdido e não reagia a estímulo da luz no olho esquerdo. Foi então que minha bisavó decidiu custear meus primeiros atendimentos no oftalmologista, uma vez que minha mãe e minha avó não tinham condições financeiras de custear esse tratamento e acompanhamento, pois já sabiam que seria algo para o resto da vida. Depois de muitas consultas e exames, fui diagnosticada com atrofia no nervo óptico. Imaginem vocês, foi uma tristeza na minha família! Júlia era cega de um dos olhos e o outro tinha estrabismo e astigmatismo.

Segundo minha família, embora cega de um olho, fui um bebê feliz e sorridente, comecei a falar muito cedo, porém, por conta da monovisão, só aprendi a andar muito tarde, mas estava tudo bem, eu era muito esperta e alegre, até que em um fatídico dia adoeci, tinha apenas um ano e oito meses, fui diagnosticada com meningite bacteriana, que me deixou internada por dois meses, submetida a tratamento com antibióticos fortíssimos que me causavam muitos efeitos colaterais. Cheguei à beira da morte, não comia nada, até que minha avó, Maria de Fátima Araújo, “Mainha Tata”, decidiu levar, escondida, mamadeiras de leite para hospital para que eu pudesse me alimentar, dessa forma, comecei a reagir, o médico falou para minha mãe que essa atitude poderia ter me matado, mas que me salvou, minha Mainha Tata é minha heroína. A meningite afetou minha motricidade, tive que reaprender a andar e a falar. Outra sequela foi uma diminuição significativa da visão direita, me tornando, a partir de então, uma garota com visão subnormal, termo que designa pessoas que tem diminuição alta e irreversível da visão, apesar de tratamentos; atualmente tenho $28 \%$ da visão.

Nesse momento minha família sabia que teria que conviver, criar e educar uma criança com deficiência visual. Ainda tenho a lembrança de como foram traumatizantes os exames, os testes e aqueles tampões horrorosos no meu olho; ficava dias no escuro para tentar estimular minha visão. Eu era um bebê de dois anos, mas ainda lembro da sensação horrível que era, não era o não enxergar nada, porque 
isso eu já conhecia com o olho cego, era o escuro total, era desesperador, eu ficava imóvel todos os dias enquanto usava o tampão; o trauma foi tão grande que tenho medo de escuro até hoje.

Com diagnóstico confirmado, minha mãe ciente de toda dificuldade que teria que enfrentar, da falta de condições financeira e guiada pela inexperiência, decidiu que seria melhor que eu fosse cuidada e criada pela minha avó. Ela não se sentiu capaz de cuidar de uma criança com uma deficiência, e saúde comprometida, pois com a imunidade muito baixa, as doenças seriam frequentes. E assim foi, Mainha Tata continuou cuidando de mim, e entre muitas idas e vindas de hospitais por muitas doenças diferentes, felizmente, consegui vencer todas e, como diziam todos os médicos, com muita garra. Por gostar muito de princesas fiquei conhecida, na minha família e nos hospitais que passava, por princesa guerreira, e não é que essa frase passou a fazer parte de mim? Até a tatuei no braço, para sempre lembrar de lutar, e não desistir diante das dificuldades.

Cresci cercada de muito amor e carinho, me sentia como uma princesa de conto de fadas, porém, como em todo reino encantado, existe o bem e o mal, me deparei com esse lado não tão bonito da vida ainda muito pequena, quando fui pra escola. Mesmo com toda dificuldade visual aprendi a ler com 3 anos, gostava de dançar, de cantar, era uma criança que se destacava no que fazia; porém, com um olho vesgo e o outro meio fechado, os tropeços e barroadas não intencionais me faziam fugir dos padrões das crianças da turma, eu era diferente, e por isso sofri muito bullying, fui descobrindo que para ser aceita ou incluída nos grupos precisaria lutar muito, mesmo sabendo que era capaz de realizar tudo que as outras crianças realizavam, foi muito dificil enfrentar tanto ódio tão nova.

A escola não é preparada para receber crianças com deficiência, a sociedade não é educada para aceitar o diferente, por conta da minha deficiência tive muitas dificuldades, por não enxergar direito era difícil realizar muitas atividades simples de uma sala de aula, como ler a prova, enxergar o quadro, e até fazer atividades 
recreativas da escola, mesmo assim não desistia, chegava todo dia machucada em casa, mas esses machucões não doíam tanto quanto a discriminação.

No ensino fundamental 2, mudei para uma nova escola, na qual estudei por quatro anos, lá tinha mais acessibilidade, fiz amigos que me ajudaram muito, lá os professores eram mais preparados para lidar com o diferente, meu caminho ainda assim não foi fácil, mas os que faziam a escola tentavam de tudo para me ajudar. Me esforcei, tirava excelentes notas, estudava madrugadas inteiras para não ficar atrás de ninguém.

Mudei de escola no ensino médio, e foi uma época incrível, fiz amigos que me aceitavam como eu sou, como Shalani, Wesley e Luiz, amizades que vou levar para o resto da vida. Ah esqueci de falar, a amizade até acabou em namoro, Luiz é meu namorado há dois anos. Fui uma aluna muito ativa em todas as atividades escolares, fui do grêmio estudantil, organizei bazares, fiz peças de teatro, sempre participava da OBMEP, SAEPE, OBF e me saia muito bem, tirava as melhores notas da escola e sempre avançava nas etapas das provas externas. Participei também de saraus, fui monitora da disciplina de física, sempre estava no quadro dos melhores alunos. Minha deficiência não me limitava, só me motivava a ser melhor e dar o meu máximo, já não me incomodava mais ser chamada por nomes cruéis relacionadas a minha visão, comecei a ser Júlia, uma aluna excelente e não mais Júlia, a caolha e cega.

Estudei muito para entrar na faculdade e realizar meus sonhos de fazer o que amo, terminar a faculdade, ser a primeira da família a fazer mestrado e doutorado. Fiquei madrugadas empenhada para fazer o Enem, e então deu tudo errado, minha prova não veio ampliada, não conseguir ler, novamente, a falta de acessibilidade tornando minha deficiência um empecilho, fiquei muito abalada. Mas respirei, e falei que não era o fim, já havia passado por tanto, não iria desistir agora, olhei para meu braço e lá estava a frase "Sempre forte como uma princesa guerreira”, me salvando mais uma vez, então fiz o vestibular do Instituto Federal de Pernambuco - IFPE, passei no curso de Design Gráfico, o qual amo cursar. 
Aos 17 anos iniciei na faculdade, uma experiencia incrível, era um mundo novo, cheio de oportunidades, e eu queria aproveitar todas elas, me empenhava muito nas disciplinas. Reencontrei uma velha amiga, Laysa e conheci uma pessoa muito especial, Bia, viramos um trio inseparável, “as amoras”, até que a pandemia veio, e tudo mudou, Laysa acabou saindo do curso e ficamos eu e Bia, uma amizade inesperada e incrível que o IFPE me deu, ela se tornou parte da minha família, me ajudou em todos os momentos. A pandemia não facilitou, eu havia acabado de ingressar na minha carreira acadêmica. Além da questão da faculdade, ainda tinha o emocional, que afetou a vida de muita gente, tanto tempo sem contato pessoal isolada, faz você começar a pensar em tudo, coisas que a correria do dia a dia não te deixava pensar. Tanto tempo no mesmo lugar te faz lembrar de coisas que você não quer lembrar. 0 tempo passava e as aulas não voltavam, a ansiedade atacava, comecei a reviver tantos sentimentos ruins e a ir para o fundo do poço, não conseguindo sair de lá, não tendo mais motivação nem vontade de fazer nada, até que a vida começou a se movimentar, procurei ajuda médica, meus amigos e família me ajudaram muito, as aulas estavam voltando mesmo que online, isso foi uma injeção de ânimo, lembrei de todos meus objetivos e fui correr atrás deles. No começo, foi difícil me adaptar ao online, tanto tempo na frente da tela era difícil, por conta da minha visão, mas isso não iria me impedir, me dediquei às disciplinas e dei meu máximo.

Tive uma cadeira em especial de gestão de negócios, lecionada pelo professor Erick Viana, que falou sobre as bolsas do PIBEX (Programa Institucional para Concessão de Bolsas de Extensão) e BIA (Bolsas de Incentivo Acadêmico), eu já havia ouvido falar, fiquei muito interessada, e pensava que, no primeiro período, participar de um projeto incrível me abriria portas para o futuro que sempre desejei! Seria um sonho! E assim foi, eu queria participar daquele projeto, seria uma porta para chegar ao meu objetivo, então me inscrevi como voluntária, pouco tempo depois tive a possibilidade de entrar como bolsista PIBEX no Projeto Despertando Vocações para Gestão de Negócios. 
Quando iniciei no projeto, sabia muito pouco, mas tinha muita sede de aprender, queria estudar e fazer um excelente trabalho, corri atrás e aprendi a fazer tudo o que me pediam. Comecei fazendo apenas cartilhas, depois fui para posts, identidades visuais, ajudar em eventos, comecei a fazer cursos, e cada vez aprendendo mais, agregando mais ao meu currículo, estudava muito para entregar o melhor trabalho possível, e para ter um bom desempenho na faculdade.

Quanto mais tempo no Projeto Despertando Vocações e no IIDV, mais me qualificava como profissional, obtendo experiências incríveis em áreas que tenho muito interesse em seguir, como diagramação, animação, ilustração; aprendendo muito como designer. Me enganei em projetos incríveis como PDV de jogos, criando identidade visual, personagens e logos; também recentemente participando de uma revista científica IJM que está sendo um trabalho incrível, uma experiência maravilhosa.

Amo trabalhar com o IIDV, e em todos os projetos que já participei. Sou muito grata ao professor Erik, porque foi através dele que surgiram todas as oportunidades, e através dele que consegui muitas conquistas. A experiência de participar desses projetos incríveis é muito especial e acredito que me torne uma profissional qualificada e preparada para o mercado de trabalho; e que portas se abram para o tão sonhado mestrado fora do país. 